\title{
Improving the energy efficiency of wide crossings of overhead power lines
}

\author{
Natalya Shevchenko ${ }^{1}$, Anatoly Soshinov ${ }^{1}$, Olga Elfimova $^{1}$, Julia Lebedeva ${ }^{1}$ and Olga Akhmedova ${ }^{1}$ \\ ${ }^{1}$ Kamyshin Technological Institute (branch) of Volgograd State Technical University, Kamyshin, Russia
}

\begin{abstract}
The use of new generation wires in the design of wide spans of overhead power lines over water barriers and large gorges can increase their transmission capacity and increase reliability. However, when large currents flow, load losses in line also increase. Thus, it is necessary to obtain a methodology for technical and economic comparison of design options for overhead power lines over large crossings, which enables to determine the most cost-effective version of the project with high mechanical reliability. For comparative analysis, five options for wide spans of overhead power lines over the river with newgeneration wires of Russian production were compiled: Aluminium Alloy Conductor Steel Reinforced, Ztype (high conductivity), Thermal-Resistant Conductor, Aluminium Compozite Core Conductor, ASk2y. Option with Aluminium Conductor Steel Reinforced wire was taken as the source. For the first option, the crossing scheme E-A-A-E was selected, for the remaining options E-I-I-E scheme was considered. For the modes of maximum loads, minimum temperature and average annual conditions, the mechanical calculation of wires was carried out using the method of permissible stresses. The wire bending deflections were determined in accordance with the theory of the catenary curve. The method of integrated indicators was used to perform a technical and economic comparison of these options. The calculation results showed that among the proposed options, the most optimal is a crossing with the ACCC wire having minimum relative investment per $1 \mathrm{MW}$ of transmitted electricity and minimal power loss. The transmission capacity of the line with this wire is increased by 1.8 times, and the cost of crossing is reduced by $16 \%$. Due to the compact design of wire, the probability of ice formation on wire is reduced, and the reduced bending deflection reduces the probability of wire break due to natural environmental influences.
\end{abstract}

\section{Introduction}

The urgent task of the power engineering sector is to optimize design solutions for wide spans of overhead power lines (OHL) through large gorges and water barriers in order to increase their reliability and current transmission capacity. When designing wide spans of $\mathrm{OHL}$, it is important to reduce the loads on transmission towers and foundations, to reduce the wire bending deflection, to reduce the probability of wire breaks and swinging during icing and squally winds $[1,2,3]$. These tasks are solved by using innovative types of wires with high electrical conductivity and high mechanical strength $[4,5,6]$.

To assess the energy efficiency of line, it is important to evaluate the level of losses of the transmitted power.

The design of wide spans of overhead power lines is carried out in accordance with the requirements of the standard "Norms of technological design of overhead power transmission lines with a voltage of $35-750 \mathrm{kV}$ " [7] and the provisions of the "Rules of Electrical Installations Design" [8]. The standard recommends to design the crossing in several ways. The final choice of options is based on a feasibility study.
In Russia, construction of wide spans through water barriers includes a practical experience of using hightemperature high-strength wires of the ACS (TACSR/ACS) brand with a steel core [9], clad with Aluminium manufactured by Lumpi-Berndorf (Austria) and EM-CABLE LLC (Russia), compacted wires with reinforced high-strength steel core AACSRZ (Lamifil LLC, Russia) [10,11,12].

\section{Problem statement}

The goal of this work is to increase the energy efficiency of a wide span of a $220 \mathrm{kV}$ double-circuit overhead power line across the river. The length of the crossing is 2080 meters.

Climatic conditions are the following: II region in terms of wind (wind speed $29 \mathrm{~m} / \mathrm{s}$ ), III region in terms of ice (ice wall thickness $b=20 \mathrm{~mm}$ ) [13].

The following tasks were set:

- To develop options for crossing of overhead line over the river using wires of a new generation of Russian production in order to increase energy efficiency;

- To select crossing schemes, types of transmission towers and wire brands; 
- To perform a mechanical calculation of wires taking into account climatic conditions and a feasibility study of the developed options.

\section{Development of options}

Based on the experience of designing and construction a wide span of $220 \mathrm{kV}$ OHL through the Kama Reservoir in 2009 [14, 15], five options for the crossing were proposed for consideration.

The first option: the crossing scheme E-A-A-E using crossing towers AT 133 and terminal towers K330$2+5 \mathrm{~K}$. The height of the AT 133 transmission tower is $154 \mathrm{~m}$, the suspension height of the lower wire is $133 \mathrm{~m}$ (Fig. 1.). Aluminium Conductor Steel Reinforced ACSR $500 / 336$ is used.

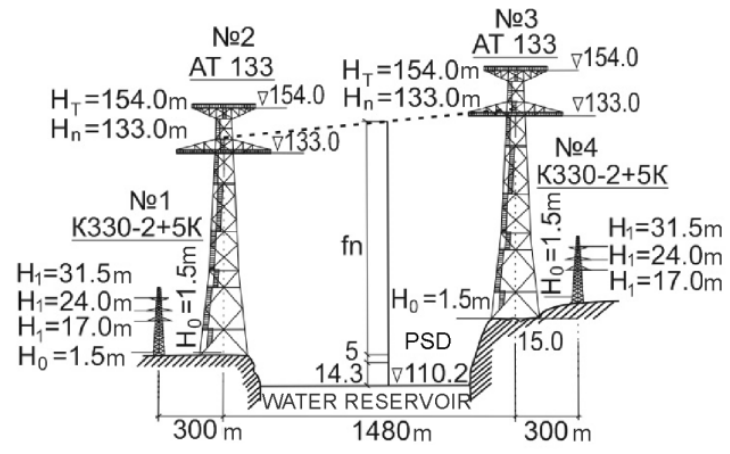

Fig. 1. The crossing scheme E-A-A-E.

The second option is using high-temperature highstrength wire TACSR/ACS 521-A20SA (Russia) with a gap between the steel wires of core and the wires of aluminium-zirconium alloys. The gap is filled with heatresistant grease. The wire has not only increased electrical conductivity, but also increased corrosion resistance owing to the use of aluminium cladding technology.

The crossing scheme E-I-I-E (Fig. 2) was selected using intermediate towers PP330-2/79.5 and terminal towers $\mathrm{K} 330-2+5 \mathrm{~K}$. The height of the PP330-2/79.5 tower was $104.4 \mathrm{~m}$, the suspension height of the lower wire was $75.2 \mathrm{~m}$.

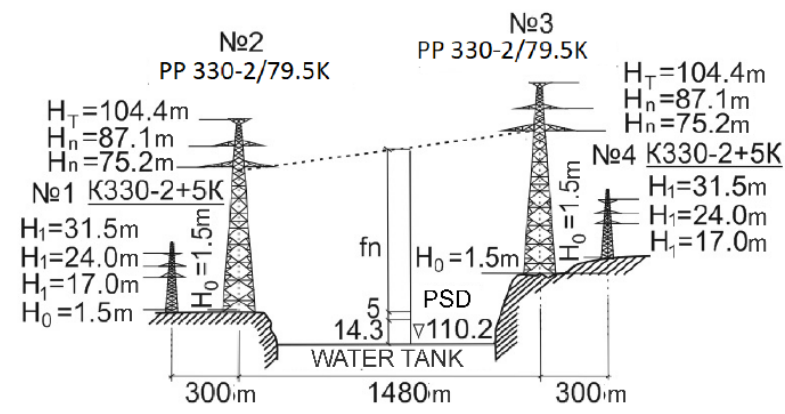

Fig. 2. The crossing scheme E-I-I-E.

Other crossing options will be performed according to the same E-I-I-E scheme with replacement of wire types, which are listed below.
Third option: AACSRZ-527 (HC) - Aluminium Alloy Conductor Steel Reinforced, Z-type (high conductivity). The conductive part has a $Z$-shaped profile, which reduces the wind resistance. Reinforced high strength steel core enhances mechanical strength of wire.

Fourth option: Aluminium Compozite Core Conductor ACCC ${ }^{\text {TM }}$ - 527. The conductive part is made of trapezoidal wires of annealed Aluminium. Core is made from basalt and carbon fibers.

Fifth option: ASk2y-527 wire. The compacted wire is made of trapezoidal Aluminium wires and a highstrength steel core with zinc- Aluminium coating. Data for comparative analysis of the considered crossing options are given in table 1 .

Table 1. Characteristics of wires of $220 \mathrm{kV}$ overhead line.

\begin{tabular}{|c|c|c|c|c|c|c|}
\hline \multirow{2}{*}{$\begin{array}{c}\text { Parame- } \\
\text { ters }\end{array}$} & \multirow{2}{*}{$\begin{array}{l}\text { Mea } \\
\text { s.u. }\end{array}$} & \multicolumn{5}{|c|}{ Wire brand } \\
\hline & & $\begin{array}{l}\text { AC } \\
\text { SR }\end{array}$ & $\begin{array}{l}\text { TAC } \\
\text { SR }\end{array}$ & $\begin{array}{l}\text { AAC } \\
\text { SRZ }\end{array}$ & $\begin{array}{l}\mathrm{AC} \\
\mathrm{CC}\end{array}$ & $\begin{array}{l}\text { ASk } \\
2 y\end{array}$ \\
\hline \multicolumn{2}{|c|}{ Options } & 1 & 2 & 3 & 4 & 5 \\
\hline $\mathrm{Fc}$ & $\mathrm{mm}^{2}$ & 826.7 & 521.0 & 526.6 & 574.8 & 562.0 \\
\hline $\mathrm{dc}$ & $\mathrm{mm}$ & 37.5 & 29.7 & 27.5 & 27.72 & 27.8 \\
\hline $\mathrm{Gc}$ & $\mathrm{t} / \mathrm{km}$ & 4.005 & 3.483 & 2.081 & 1.54 & 1.853 \\
\hline $\mathrm{E}$ & $\begin{array}{l}\mathrm{kN} / \\
\mathrm{mm}^{2}\end{array}$ & 114.0 & 154.6 & 85.9 & 116.0 & 79.3 \\
\hline RTS & $\mathrm{kN}$ & 467 & 666 & 312.4 & 159.1 & 175.6 \\
\hline $\begin{array}{c}\alpha \\
\text { (TKLP) }\end{array}$ & $\begin{array}{l}10^{-6} \% \\
{ }^{\circ} \mathrm{K}\end{array}$ & 15.5 & 12.6 & 17.39 & 1.61 & 18.1 \\
\hline \multicolumn{2}{|c|}{$\begin{array}{l}\text { Tower } \\
\text { reference }\end{array}$} & $\begin{array}{l}\text { AT } \\
133\end{array}$ & \multicolumn{4}{|c|}{ PP330-2/79.5 } \\
\hline $\begin{array}{l}\text { Tower } \\
\text { mass }\end{array}$ & $\mathrm{kg}$ & 400 & \multicolumn{4}{|c|}{154.4} \\
\hline
\end{tabular}

\section{Mechanical calculation}

The mechanical calculation of wires and cables of wide spans is carried out according to the method of permissible stresses for maximum load conditions, minimum temperature and average annual conditions. The voltage at any point of wire is found from the equation [16]:

$$
\sigma-\frac{\sigma}{\gamma \beta} \operatorname{ch} \frac{\gamma l}{2 \sigma} \cdot \frac{1}{\frac{\sigma_{m}}{\gamma_{m}} \cdot \operatorname{ch} \frac{\gamma_{m} l}{2 \sigma_{m}}}=\sigma_{m}-\frac{1}{\beta}-\frac{\alpha}{\beta}\left(t-t_{m}\right)
$$

where $\sigma, \sigma_{\mathrm{m}}$ are voltage and permissible voltage in the material of wire or cable in one of the considered modes, respectively;

$\gamma, \gamma_{\mathrm{m}}$ are the specific mechanical load of wires, $\mathrm{N} / \mathrm{m}$. $\mathrm{mm}^{2}$;

$\beta, \alpha$ are the coefficients of elastic elongation and thermal expansion; 
$t, t_{m}$ are the temperatures typical for the calculated or known mode.

The overall bending deflections when crossing a large gorge or water barriers are determined in accordance with the requirements of the "Rules of Electrical Installations Design". For high-temperature wires, it should be determined at the maximum permissible wire temperature.

The wire bending deflection is determined in accordance with the theory of the catenary curve.

At different heights of suspension points, wire bending deflections corresponding to the large and small equivalent spans are determined by formulas (2) and (3):

$$
\begin{gathered}
f_{1}=\frac{\gamma \cdot l_{e g_{1}}^{2}}{8 \cdot \sigma_{0}} ; f_{2}=\frac{\gamma \cdot l_{e g_{2}}^{2}}{8 \cdot \sigma_{0}} ; \\
f_{2}=-\frac{\sigma}{\gamma} \cdot \ln \cos \frac{\gamma \cdot x_{0}}{\sigma} ; f_{1}=f_{2}+\Delta h .
\end{gathered}
$$

Wire deflections in the span at different heights of suspension points are shown in Fig. 3 [17].

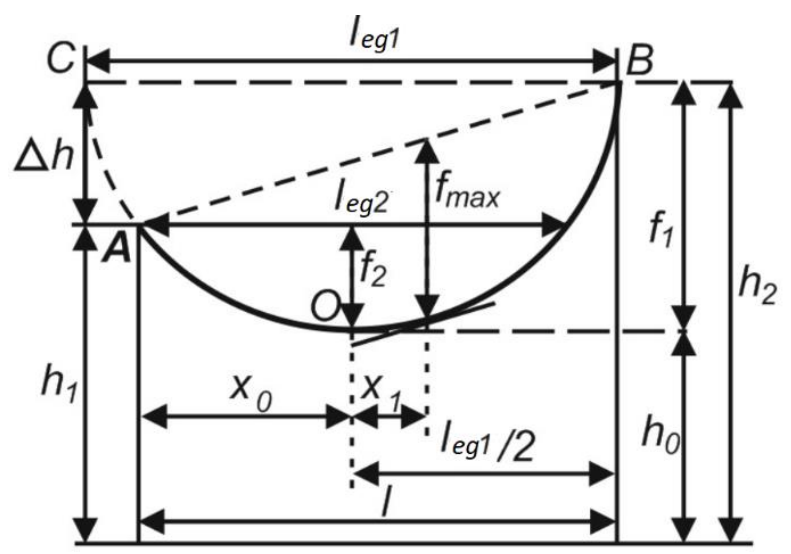

Fig. 3. Determination of wire deflections in the span for various heights of suspension points.

\section{Results of mechanical and technical and economic calculations}

The wire length in span $L$ is determined taking into account the deflection $f$ according to the formula:

$$
L=l+\frac{8 \cdot f^{2}}{3 \cdot l} .
$$

The integral effect Ie is taken as a criterion of profitability [18]:

$$
I_{e}=\sum_{t=0}^{T}\left(R_{t}-Z_{t}\right) \cdot \frac{1}{(1+E)^{t}}-\sum_{t=0}^{T} K_{t} \cdot \frac{1}{(1+E)^{t}},
$$

where $\mathrm{R}_{\mathrm{t}}$ is the income received at the $\mathrm{t}$-th calculation step;

$\mathrm{Z}_{\mathrm{t}}$ is the costs at the $\mathrm{t}$-th calculation step;

$\mathrm{T}$ is the planning horizon, taken 13 years;
$\sum_{t=0}^{T^{\prime}} K_{t}$ is the cost of crossing, million rubles;

$\mathrm{E}$ is the discount rate;

$t$ is the number of calculation step.

The results of calculation of the considered crossing

\begin{tabular}{|c|c|c|c|c|c|c|}
\hline \multirow{2}{*}{ Parameters } & \multirow{2}{*}{$\begin{array}{l}\text { Mea } \\
\text { s. u. }\end{array}$} & \multicolumn{5}{|c|}{ Options } \\
\hline & & 1 & 2 & 3 & 4 & 5 \\
\hline $\begin{array}{l}\text { Bending } \\
\text { deflection, } f\end{array}$ & $\mathrm{~m}$ & $\begin{array}{l}145 . \\
6\end{array}$ & 86.0 & 66.1 & 49.0 & 62.4 \\
\hline $\begin{array}{l}\text { Length of } \\
\text { wire in span, } \\
\text { L }\end{array}$ & $\mathrm{km}$ & $\begin{array}{l}12.7 \\
4\end{array}$ & 12.0 & $\begin{array}{l}12.6 \\
0\end{array}$ & $\begin{array}{l}12.5 \\
1\end{array}$ & $\begin{array}{l}12.6 \\
1\end{array}$ \\
\hline $\begin{array}{l}\text { Weight of } \\
\text { wire in span }\end{array}$ & $\mathrm{t}$ & 51.0 & 44.2 & 26.2 & 19.8 & 23.2 \\
\hline $\begin{array}{l}\text { Cost of } \\
1 \mathrm{t} \text { of wire }\end{array}$ & $\begin{array}{l}\text { ths. } \\
\text { rub. }\end{array}$ & 175 & 525 & 525 & 700 & 350 \\
\hline $\begin{array}{l}\text { Cost of wire } \\
\text { in span }\end{array}$ & $\begin{array}{l}\text { mln. } \\
\text { rub. }\end{array}$ & 8.93 & 23.2 & 13.8 & 13.9 & 8.11 \\
\hline $\begin{array}{l}\text { The cost of } \\
\text { crossing, K }\end{array}$ & $\begin{array}{l}\text { mln. } \\
\text { rub. }\end{array}$ & $\begin{array}{l}192 . \\
7\end{array}$ & $\begin{array}{l}171 . \\
4\end{array}$ & $\begin{array}{l}162 . \\
0\end{array}$ & $\begin{array}{l}162 . \\
1\end{array}$ & $\begin{array}{l}156 . \\
3\end{array}$ \\
\hline $\begin{array}{l}\text { Cost } \\
\text { reduction }\end{array}$ & $\%$ & - & 11.0 & 16.0 & 15.9 & 18.9 \\
\hline
\end{tabular}
options are given in Table 2.

Table 2. Characteristics of wires of the $220 \mathrm{kV}$ overhead line crossing.

An important indicator of effective functioning of an overhead power line is the minimum loss of electricity. To assess the technical efficiency of crossing, we introduce the concept of the energy coefficient $\mathrm{K}_{\mathrm{e}}$ [1922].

$$
K_{e}=\frac{W_{\mathrm{re}}}{W_{\mathrm{re}}+\Delta W_{L}+\Delta W_{C L}},
$$

where $W_{\text {re }}$ is the transmitted electricity,

$\triangle W_{L}$ is the load losses of electricity;

$\triangle W_{C L}$ is the corona electricity losses.

Maximum transmitted power is:

$$
P_{\max }=1.05 \cdot \sqrt{3} \cdot I_{\max } \cdot U_{\text {rat }} \cdot \cos \varphi .
$$

where $I_{\max }$ is the maximum line current, A;

$\cos \varphi$ is the power factor, taken 0.9;

$U_{\text {rat }}$ is the rated voltage of the network, taken $220 \mathrm{kV}$.

Transmitted electricity per year $W_{r e}$ :

$$
W_{\text {re }}=P_{\max } \cdot T_{\max }
$$

where $T_{\max }$ is the number of hours of maximum load use, taken $T_{\max }=6000 \mathrm{~h}$.

Load losses of electricity in line are:

$$
\Delta W_{\mathrm{L}}=3 \cdot I_{\max }^{2} \cdot L \cdot r_{0} \cdot \tau
$$

where $\tau$ is the maximum loss time, taken $4500 \mathrm{~h}$.

The calculation results are presented in Table 3. 
Table 3. Parameters of the $220 \mathrm{kV}$ OHL crossing wires.

\begin{tabular}{|c|c|c|c|c|c|c|}
\hline \multirow{2}{*}{$\underset{\text { rs }}{\text { Paramete }}$} & \multirow{2}{*}{$\begin{array}{c}\text { Meas. } \\
\text { u. }\end{array}$} & \multicolumn{5}{|c|}{ Options } \\
\hline & & 1 & 2 & 3 & 4 & 5 \\
\hline$t_{\max }$ & ${ }^{\circ} \mathrm{C}$ & 90 & 150 & 90 & 180 & 90 \\
\hline$I_{\text {all }}$ & A & 960 & 1344 & 979 & 1867 & 1360 \\
\hline $\mathrm{P}_{\max }$ & MW & $\begin{array}{c}345 . \\
3\end{array}$ & $\begin{array}{c}483 . \\
84\end{array}$ & $\begin{array}{c}352 . \\
44\end{array}$ & $\begin{array}{c}672 . \\
12\end{array}$ & $\begin{array}{c}489 . \\
6\end{array}$ \\
\hline $\begin{array}{l}\text { ro at } 20 \\
{ }^{\circ} \mathrm{C}\end{array}$ & $\begin{array}{c}\mathrm{kOhm} / \\
\mathrm{km}\end{array}$ & 58.8 & $\begin{array}{c}166 . \\
5\end{array}$ & 77.5 & 54.5 & 58.2 \\
\hline $\mathrm{W}_{\mathrm{re}}$ & $\begin{array}{l}\mathrm{MW} \cdot \mathrm{h} \\
\cdot 10^{5}\end{array}$ & 20.7 & 29.0 & 21.2 & 38.4 & 29.5 \\
\hline$\Delta W \Sigma$ & $\begin{array}{c}\mathrm{MW} \cdot \mathrm{h} \\
\cdot 10^{5}\end{array}$ & 0.14 & 0.75 & 0.20 & 0.46 & 0.29 \\
\hline $\mathrm{Ke}_{\mathrm{e}}$ & $\%$ & 99.3 & 97.4 & 99.0 & 98.8 & 99.0 \\
\hline$I_{e}$ & $\begin{array}{l}\text { bln. } \\
\text { rub. }\end{array}$ & 19,1 & 26.1 & 19.4 & 35.2 & 27.1 \\
\hline $\begin{array}{l}\text { Relative } \\
\text { capital } \\
\text { investmen } \\
\text { ts }\end{array}$ & $\begin{array}{l}\text { mln. } \\
\text { rub./ } \\
\text { MW }\end{array}$ & 0.56 & 0.35 & 0.46 & 0.24 & 0.32 \\
\hline
\end{tabular}

The calculations show that among the proposed options, the most optimal is crossing with ACCC wire having minimum relative investment per $1 \mathrm{MW}$ of transmitted power. The transmission capacity of line with this wire is increased by 1.8 times, and the cost of crossing is reduced by $16 \%$. The smaller diameter of wire reduces the probability of ice formation on the wire, and the reduced bending deflection reduces the probability of wire break due to natural environmental influences.

\section{Conclusions}

The results of calculations of a wide crossing of $220 \mathrm{kV}$ overhead transmission line over the river showed that the use of modern types of wires can solve the problem of both increasing the transmission capacity of overhead power lines and increasing their reliability.

The cost of span construction is reduced by $11-19 \%$ due to the possibility of using towers and foundations of lower material consumption.

\section{References}

[1] Liqiang An, Yongyu Guan, Zhijian Zhu, Jiong Wu, Ronglun Zhang, Engineering Failure Analysis 104, 911-931 (2019).

[2] Guohong Chen, Xu Wang, Jiaqing Wang, Jun-jian Liu, Wenming Tang, Engineering Failure Analysis 19, 13-21 (2012).

[3] S. Karabay, F. Kaya Önder, Electric Power Systems Research 72, 21, 179-185 (2004).

[4] S. Karabay, Materials and Design 30, 3, 816825 (2009).
[5] R.B. Kalombo, J.M.G. Martínez, J.L.A. Ferreira, C.R.M. da Silva, J.A. Araújo, Procedia Engineering 133, 223-232 (2015).

[6] N. Fedorov, Overhead lines 1, 6, 31-34 (2012)

[7] STO 56947007, Norms of technological design of overhead power transmission lines with a voltage of $35-750 \mathrm{kV}$ (2014).

[8] Rules of Electrical Installations Design, Russian Electrical Code, 7th Edition, All sections and exhibits, Saint-Petersburg, 928 (2000).

[9] R.C.R. de Mendez, J.D. Riera, L.F.F. Miguel, J. Kaminski Jr, L.F.F. Miguel, J.B.G. Ferreira da Silva, On Modeling the Dynamic Response of the 190m-high Tower for the Crossing of Trombetas River in the Amazon Region, CIGRE Session, B2-212 (2012).

[10] B. Subba Reddy, Diptendu Chatterjee, Energy Procedia 90, 179-184 (2016).

[11] G.S. Rashmi, Shivashankar, Poornima, Materials Today: Proceedings 4, 10, 11318-11324 (2017).

[12] C.R.F Azevedo, T. Cescon, Engineering Failure Analysis 9, 6, 645-664 (2002).

[13] I. Levchenko, A. Zasypkin, A. Alliluyev, E. Satsuk (Moscow: Publishing House of Mos-cow Power Engineering Institute, 447, 2007).

[14] V. Kachanovskaya, M. Yermoshina, Electricity, Transmission and distribution 1, 16, 50-54 (2013).

[15] V. Kachanovskaya, M. Yermoshina, Transmis-sion and Distribution World, USA, 52-54 (2013).

[16] A. Boshnyakovich, Calculation of substation wires and large overhead power line crossings (Leningrad: Energy, 236, 1975).

[17] M. Korotkevich, N. Prokofiev, Power engineer-ing, Energetika, Proceedings of CIS higher edu-cation institutions and power engineering associations 61, 5, 432-439 (2018).

[18] G. Ugarov, N. Shevchenko, Yu. Lebedeva, A. Soshinov (Moscow: Pero, 186, 2013).

[19] Yu. Lebedeva, N. Shevchenko, A. Soshinov, Modern problems of science and education 6, 68-71 (2010).

[20] N. Shevchenko, Izvestiya VolgGTU, Series: Energy Conversion Processes and Power Plants 8, 3, 8992 (2011).

[21] N. Shevchenko, Yu. Lebedeva, G. Ugarov, Vestnik SGTU 1, 3, 121-125 (2011).

[22] N. Shevchenko, Abstract of the dis. Cand. Technical Sciences 05.09.03 (Saratov, 20, 2011). 